Bull. Egypt. Soc. Physiol. Sci. Vol. (41) Issue (2), 184- 202

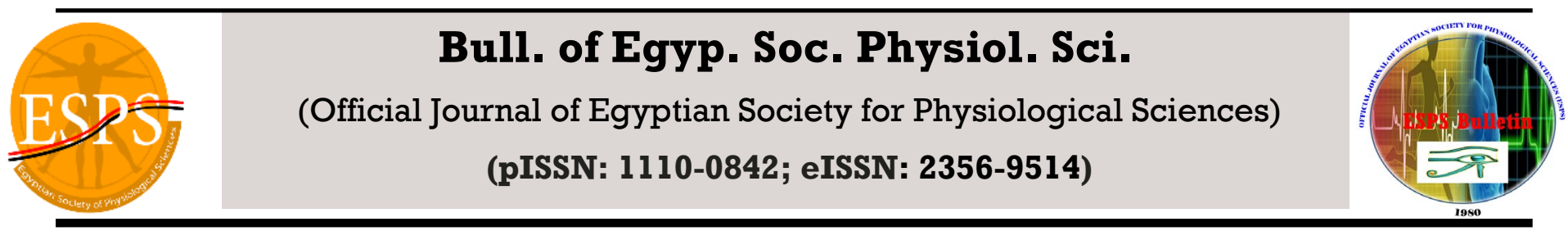

\title{
Topical Hypothermia is More Efficient Than Ischemic Preconditioning in Ameliorating Hepatic Ischemia Reperfusion Injury in Rat Liver Through Hypoxia Inducible Factor Independent Mechanisms
}

\author{
Bataa M.A. ElKafoury, Doaa M. Abdel Wahed, Eman K. Habib, Nermeen E. Selim*, Mohamed H. El Sayed \\ Physiology Department, Faculty of Medicine, Ain Shams University, Cairo, Egypt.
}

Submit Date: June, 26, 2020

Revise Date: July 25, 2020

Available online: Jan 10, 2021

\section{Keywords}

- Ischemia reperfusion injury

- Hepatic hypothermia,

- Hepatic ischemic preconditioning

- Hypoxia inducible factor $1 \alpha(\mathrm{HIF} 1 \alpha)$

- ATP

\section{Abstract}

Background: Hepatic ischemia reperfusion (IR) injury is common with many medical strategies as liver transplantation and trauma. Aim: is comparing the efficacy and evaluating the possible mechanisms of ischemic preconditioning (IPC) and topical hypothermia $(\mathrm{TH})$ in the hepatic IR injury. Method: 56 adult male albino rats were allocated into four groups: sham control group $(n=15)$, hepatic ischemia reperfusion group (IR) ( $\mathrm{n}=13$ ): where ischemia compromised $70 \%$ of the liver for $45 \mathrm{~min}$ followed by 90 min of reperfusion, topical hypothermia (TH-IR) group ( $n=14)$ : liver temperature was maintained during ischemia at $10^{\circ} \mathrm{C}$, ischemic preconditioning group (IPC-IR) $(n=14)$ : 10 minutes of ischemia followed by 10 minutes of reperfusion prior to hepatic ischemia reperfusion. ALT, AST and ALP were measured in serum while malondialdehyde (MDA), glutathione peroxidase (GPX), hypoxia inducible 1 alpha (HIF1 $\alpha$ ), tumor necrosis factor alpha (TNF $\alpha)$, cytochrome c (Cyt c), adenosine triphosphate (ATP) and dynamine related protein (DRP1) were measured in hepatic tissue in addition to the histological examination. Results: TH and IPC significantly reduced AST, MDA, TNF $\alpha$, Cyt $\mathrm{c}$ and DRP1 expression. TH preserved hepatic integrity, normalized both AST and ALT, increased hepatic GPX and reduced MDA while IPC did not increase GPX and has less significantly reduced MDA compared to hypothermia. ATP was significantly higher with hypothermia compared to IPC. Hypothermia decreased significantly the level of HIF $1 \alpha$ while preconditioning increased its level. Conclusion: Hypothermia was more protective against IR injury compared to IPC despite reduced metabolic reprogramming signal HIF1 $\alpha$. Hypothermia effect was through improvement of REDOX state and mitochondrial bioenergetics.

Corresponding author: Dr Nermeen E. Selim: Physiology Department, Faculty of Medicine, Ain Shams University, Cairo, Egypt, mob:+201022464692, Email: nermeen_selim86@hotmail.com 


\section{INTRODUCTION}

Ischemic reperfusion (IR) injury is common with many medical strategies such as percutaneous coronary intervention and coronary artery bypass grafting (1), effective thrombolysis therapy of stroke (2) and might be considered the transplant surgeon's enemy during kidney transplantation (3).

The liver is subjected to two types of IR injury, the first type takes place during liver surgery, trauma and hemorrhagic shock and called warm IR injury while the second form occurs during the hypothermic preservation and storage of the organ for transplantation and called cold IR injury (4). Vascular occlusion techniques are used for avoiding excessive blood loss during liver surgery (5). Thus, a better understanding of hepatic IR injury may lead to improvements of the clinical care of many patients, particularly those undergoing surgery with extended ischemia.

The mechanisms of hepatic IR injury are attributed to multiple factors such as oxidative stress and ROS generation through multiple pathways $(6,7)$. For instance, it reduces ATP availability resulting in $\mathrm{Ca}^{++}$channels failure and its accumulation inside the cells with a subsequent activation of intracellular enzymes such as phospholipase $\mathrm{C}$, protein kinase $\mathrm{C}$ which induces hepatic necrosis and apoptosis. IR injury also disturbs mitochondrial function due transition of mitochondrial membrane permeability and mitochondrial swelling (8). Additionally, it increases also transcription of inflammatory chemokines and cytokines such as TNF $\alpha$, interleukins (IL) and Interferons (9). In addition, prolonged IR injury causes cell damage via enhanced incidence of apoptosis, autophagy, necrosis, and necroptosis (10) and it affects mitochondrial dynamics such as excessive mitochondrial fission (11).

Therapeutic Hypothermia has been proved by the experimental studies in animals to have neuroprotective effects (12) and to reduce the risk of renal failure after renal IR injury (13). Hypothermia also protects livers from reperfusion injury (14) and decreases myocardial infarction size (15). The previous effects were explained by the ability of hypothermia to improve the REDOX state (16), to decrease the expression of inflammatory markers as TNF $\alpha$, IL1 $\beta$, IL6, and IL12 (17), to have potent anti-apoptosis activity (18), to decrease the effect of IR on mitochondrial activity and to increase the energetic bioavailability (19). These effects of hypothermic perfusion lead to a scientific thinking to use hypothermia as a preconditioning model in isolated perfused rat liver $(20,21)$ and to provide a promising strategy to prepare the liver against ischemic damage (22).

On the other hand, little is known about clinical application of hypothermia in human. Hypothermia was reported to represent a doubleedged sword: if hypothermic preservation can help against the damaging effects of ischemia, a prolonged hypothermia can be accompanied by worse recovery which was observed with renal recovery during kidney transplantation and was suggested to lead to mitochondrial dysfunction and pro-apoptotic signal transduction Hypothermia with its advantages has been reported also to have undesirable side effects, including cell swelling, acidosis, altered enzyme activity, calcium accumulation, and production of ROS (24). 
Ischemic preconditioning (IPC) means transient brief episodes of sublethal ischemia preceding a subsequent prolonged ischemia, which has been found to enhance organ resistance to ischemic injury (ischemic tolerance) as manifested in diverse organs and tissues including the heart, brain, liver and kidney (25). Additionally, IPC was reported to suppress mitochondrial depolarization, improved ATP production and inhibited the generation of reactive oxygen species ( ROS)

(26). However, the exact mechanism by which IPC confers protection against hepatic IR injury has not been completely elucidated (27). Few studies have reported that IPC does not prevent hepatic IR injury (28) while other studies were advised to confirm the benefit of IPC during hepatic IR injury (27).

In this study the efficacy of both IPC and topical hypothermia preconditioning to ameliorate hepatic IR injury are going to be evaluated. In addition, the study tries to probe if there are any differences in the mechanisms by which they interact with the hepatic tissue. Therefore, the changes in liver cell integrity as deduced by histological examination and biochemical assays of hepatic and mitochondrial functions in addition to evaluation of the REDOX state are going to be studied as possible interactive mechanisms.

\section{Material and Methods:}

\section{Experimental Animals:}

The study was performed on 56 male albino adult rats, weighing 180-250 grams at the start of the study. Rats were maintained in the Medical Ain Shams Research Institute (MASRI) under standard conditions of boarding throughout the whole period of the study.
Animals were housed in animal cages (4rats / cage) with suitable ventilation, temperature of $22-25^{\circ} \mathrm{C} ; 12$ hours light dark cycle and free access to food and water ad-libitum in the animal house. Animals were not exposed to unnecessary pain or stress. Animal manipulation was performed with maximal care and hygiene.

All rats received care in accordance with the national health guidelines and the research ethical committee of Faculty of Medicine Ain Shams University. Further the Ain Shams Faculty of Medicine Ethical Committee approval was obtained.

\section{Experimental protocol:}

Starting number of rats in each group was 15 with total 60 rats for the four groups and the final number is 56 rats due to death rate of 2 rat in IR group, of 1 rat in TH group and 1 rats in IPC group.

Rats were randomly allocated into 4 groups:

1- Sham control group $(\mathrm{n}=15)$

2- Hepatic ischemia reperfusion group (IR) $(\mathrm{n}=13)$

3- Topical hypothermia(TH-IR) group $(n=14)$

4- Ischemic preconditioning group (IPC-IR) $(n=14)$

\section{Experimental procedures:}

Ischemia reperfusion: On the day of sacrifice, rats were weighed and injected intraperitoneally by sodium thiopental in a dose of $40 \mathrm{mg} / \mathrm{kg}$ body weight (29). After a midline laparotomy, all structures in the portal triad (hepatic artery, portal vein, and bile duct) to the left lobe and median liver lobes were occluded with atraumatic microvascular clamp for 45 minutes. The occlusion spared to the branches of the right and 
caudate lobe resulting in 70\% liver ischemia (30).

Reperfusion was done by the end of 45 minutes ischemia by removal of the clamp for 90 minutes (31). The wound was closed temporarily by $2-0$ silk sutures during reperfusion. This method of partial hepatic ischemia prevented mesenteric venous congestion by permitting portal decompression through the right and caudate lobes (32).

Induction of topical hypothermia: In the hypothermia group a plate made of polystyrene was placed over the rat body to isolate the left lateral and median liver lobes from other body parts in order to avoid induction of systemic hypothermia. After induction of ischemia the isolated lobes were surrounded by packs filled with ice. Ice packs were replaced every 10-15 min with new ones. A surface probe (Digital Thermometer (ranging from $-50^{\circ} \mathrm{C}$ to $300^{\circ} \mathrm{C}$, China ) was placed between median and lateral left lobes to measure the liver core temperature that was maintained at $10^{\circ} \mathrm{C}$ (33). Rats body were covered by warm blankets and body temperature was continuously monitored rectally with the rectal digital Thermometer (Rosamax, Switzerland) to keep body temperature between $36^{\circ} \mathrm{C}$ and $37^{\circ} \mathrm{C}$ that was monitored (33).

Ischemic preconditioning: In the Ischemic preconditioning group, Ischemic preconditioning was produced by 10 minutes of ischemia followed by 10 minutes of reperfusion prior to the 45 minutes of ischemia which is followed by 90 minutes of reperfusion (34).

In the sham group, all structures in the portal triad were exposed but were not subjected to ischemia.
Sample collection: At the end of reperfusion period, the abdominal aorta was exposed and blood was collected into serum tubes which were stored at -80 until subjected to the biochemical assays. Median lobe of the liver was stored at $80^{\circ} \mathrm{C}$ until subjected to the biochemical assays. Parts of the left lobe of the liver were preserved in $10 \%$ formalin for $\mathrm{H} \& \mathrm{E}$ examination of the hepatic tissue. 8 samples of hepatic tissue were taken for measurement of HIF $1 \alpha$ and TNF $\alpha$ and 6 hepatic tissue samples were taken for measurement of Cyt c, ATP and DRP1.

\section{Biochemical analysis:}

Determination of serum level of ALT, AST and ALP:

Serum liver enzymatic activity: Alanine amino transferase (ALT), Aspartate aminotransferase (AST) were measured colorimetrically according to manufacturer's protocol using commercial kits supplied byBio-diagnostic (Egypt).

Serum alkaline phosphatase (ALP): was measured colorimetrically according to manufacturer's protocol using commercial kits supplied by Bio-diagnostic (Egypt).

Determination of hepatic tissue level of MDA and glutathione peroxidase (GPX) activity:

Prior to tissue homogenization, the frozen hepatic tissue at $-80^{\circ} \mathrm{c}$, was allowed to thaw and was perfused with a PBS (phosphate buffered saline) solution, $\mathrm{pH} 7.4$ containing $0.16 \mathrm{mg} / \mathrm{ml}$ heparin to remove any red blood cells and clots. The tissue sample was cut thoroughly, weighed and homogenized. The tissue was homogenized in $6 \mathrm{ml}$ cold buffer $(50 \mathrm{mM}$ potassium phosphate, $\mathrm{pH}$ 7.5.) per gram tissue. Hepatic tissue homogenization was performed, using the 
homogenizer: Karl Kolb, scientific technical supplies D-6072, Dreieich, West Germany. Samples were centrifuged at 4000 r.p.m for 15 minutes and the supernatant was removed for assay and stored at -80 to measure levels of MDA and GPX in hepatic tissue.

Hepatic tissue malondialdehyde (MDA): was measured by colorimetric method according to manufacturer's protocol using kits supplied by Biodiagnostics, (Egypt). While Hepatic tissue glutathione peroxidase (GPX) activity was measured by UV method according to manufacturer's protocol using kits supplied by Biodiagnostics, (Egypt).

\section{Determination of HIF1 $\alpha$, TNF $\alpha$, Cyt $\mathrm{c}$ and ATP} levels in hepatic tissue.

8 tissue samples were taken for measurement of HIF1 $\alpha$ and TNF $\alpha$. Also 6 tissue samples were taken for the measurements of cyt c, ATP and DRP1.

Hepatic tissue homogenization was performed in the homogenization buffer ( $\mathrm{pH}: 7.2)$ by adding $9 \mathrm{~mL}$ buffer for each $1 \mathrm{gm}$ tissue. The homogenization HEPES buffer (Sigma) consisted of: (4-(2-hydroxyethyl)-1-piperazineethanesulfonic acid) (HEPES), ethylene-diamine-tetraacetic acid (EDTA), Dithiothreitol (DTT), phenylmethylsulfonyl fluoride (PMSF). After homogenization, samples were centrifuged for 5 min. at 5000 r.p.m. The supernatant was separated and used for determination of HIF $1 \alpha$, TNF $\alpha$, ATP and Cyt c levels in hepatic tissue. For ATP measurement hepatic tissue was homogenized (10 $\mathrm{mg}$ ) in $100 \mathrm{ml}$ ATP assay buffer.

\section{Hepatic tissue hypoxia-inducible factor 1alpha}

(HIF1 1): was estimated by enzyme-linked immunosorbent assay (ELISA) according to manufacturer's protocol using kits supplied by (Fine Test, China).

Hepatic tissue tumor necrosis factor alpha (TNF $\alpha)$ : were estimated by ELISA according to manufacturer's protocol using kits supplied by (Fine Test, China).

Hepatic tissue cytochrome c (Cyt c): Assays of liver tissue levels of Cyt c was carried out by ELISA, according to manufacturer's protocol, using kits for rat supplied by (Elabscience, USA).

Hepatic tissue ATP level: was measured colorimetrically, according to manufacturer's protocol using commercial kits supplied byBiovision (USA).

\section{Determination of Hepatic tissue Dynamine related protein (DRP1):}

It was measured by using polymerase chain reaction (PCR), at first total RNA extraction was performed using Qiagen tissue extraction kit (Qiagen, USA) according to instructions of manufacture. The total RNA $(0.5-2 \mu \mathrm{g})$ was used for cDNA conversion using high capacity cDNA reverse transcription kit Fermentas, USA). Quantitative PCR used SYBR Green I Master mix and analysis were performed using an Applied Biosystem with software version 3.1 (StepOne $^{\mathrm{TM}}$, USA). The qPCR assay with the primer sets were optimized at the annealing temperature. DRP1expression were normalized to the $\beta$-actin . The primer sequence for DRP1 was (Forward primer:5'- GGAATCTTCTTCATTCCTGAC -3, Reverse primer: 5'- CCAGTGCAGGGTCCGAGGT $3)$, while the primer sequence of $\beta$ eta actin was (Forward primer 5'-TGTTTGAGACCTTCAACACC3', and Reverse primer 5'CGCTCATTGCCGATAGTGAT-3'). The relative quantitation was calculated according to Applied 
Bio system software using specific applied equations.

\section{Histological examination of liver tissue:}

Left lobes of liver were fixed in $10 \%$ neutral-buffered formalin solution. The specimens were dehydrated in ascending grades of alcohol, cleared in xylene and embedded in paraffin wax. Serial sections, 5 um thick were cut and stained with Hematoxylin and Eosin. The stained sections were examined by using the light microscope for evaluation of histological changes (35).

\section{Statistical analysis}

Data were expressed as means \pm SEM. ANOVA was used to find significance between means of multiple groups. This is followed by LSD (least significant difference) to find intergroup statistical significance with $\mathrm{p} \leq 0.05$ considered significant. For correlation studies, person correlation coefficient was calculated by linear regression analysis using the Least Square Method and correlation of $\mathrm{p} \leq 0.05$ was considered statistically significant.

All statistical data were analyzed using SPSS program (Statistical Package for Social Science) version 20 (36).

\section{Results:}

Ischemia reperfusion injury resulted in significant increase in both ALT and AST compared to sham control group. Hypothermia resulted in significant decrease in both ALT and AST compared to IR group without significant difference to its corresponding values in control. Ischemic preconditioning resulted only in significant decrease in AST compared to IR but it is significantly higher than control. In addition, preconditioning showed no significant difference in ALT when compared to IR group. There was also no significant difference in ALP between all the studied groups (Table 1).

Regarding the oxidative stress biomarker, MDA level was significantly increased in IR group compared to sham group with significant decrease in GPX level compared to sham group. Hypothermia significantly decreased oxidative marker MDA and increased antioxidant enzyme GPX compared to IR group. IPC in this study decreased significantly the level of MDA compared to IR group but its level was significantly higher compared to its corresponding value in hypothermic group. IPC showed no significant change in level of GPX compared to IR group where its level was significantly less than sham control and significantly less than its corresponding values in hypothermic group (Table 2).

IR group showed significant increase in $\mathrm{TNF} \alpha$ compared to control group. Rats in topical hypothermia and IPC groups showed significant decrease in TNF $\alpha$ compared to IR rats. However, topical hypothermia and IPC remained significantly higher in their TNF $\alpha$ level compared to sham control rats (Table 2).

IR significantly increased HIF $1 \alpha$ compared to sham control group. Topical hypothermia showed significant decrease in HIF1 $\alpha$ level compared to IR injury group, while IPC significantly increased HIF $1 \alpha$ compared to IR injury and hypothermic groups (Figure 1).

ATP level significantly decreased in the IR group compared to sham group. Rats after topical hypothermia and IPC showed significant increase in ATP level compared to IR injury group. However, hypothermia manifested higher 
ATP compared to preconditioning. Compared to control the level of ATP in both hypothermia and IPC groups remained significantly low (Figure 1).

Ischemia reperfusion showed significant increase in Cyt $\mathrm{c}$ and DRP1 level compared to sham control group. Both topical hypothermia and IPC resulted in significant decrease in both Cyt c and DRP1 level compared to IR injury group but the level remained significantly higher than control group (Figure 1).

As shown in Table (3) in the different studied groups except in control group, there is positive significant correlation between the level of serum AST and the hepatic tissue level of MDA, TNF $\alpha$, Cyt $\mathrm{c}$ and DRP1. On the other hand a negative significant correlation was observed between the serum level of AST and hepatic GPX and ATP. Also there is a positive correlation between ALT and both of MDA and TNFa. In addition, there was a positive significant correlation between the level of MDA and the level of HIF $1 \alpha$ as shown in (Figure 2)

Table (1): Serum levels of alanine transaminase enzyme (ALT), aspartate transaminase enzyme (AST) and alkaline phosphatase enzyme (ALP) in the different studied groups.

\begin{tabular}{|c|c|c|c|c|}
\hline & Sham control & $\begin{array}{c}\text { Ischemia reperfusion } \\
\text { (IR) }\end{array}$ & $\begin{array}{c}\text { Topical hypothermia } \\
\text { (TH-IR) }\end{array}$ & $\begin{array}{c}\text { Ischemic } \\
\text { preconditioning } \\
\text { (IPC-IR) }\end{array}$ \\
\hline No. & (15) & (13) & (14) & (14) \\
\hline $\begin{array}{c}\text { (ALT, } \mathbf{I U} / \mathbf{L}) \\
\text { Mean } \\
\pm S E M \\
a \\
b \\
c \\
\end{array}$ & $\begin{array}{c}43.3 \\
4.2\end{array}$ & $\begin{array}{c}\mathbf{6 4 . 0} \\
\mathbf{4 . 8} \\
<0.001\end{array}$ & $\begin{array}{c}\mathbf{4 7 . 7} \\
\mathbf{3 . 5} \\
N S \\
<0.01\end{array}$ & $\begin{array}{c}\mathbf{5 7 . 1} \\
\mathbf{2 . 4} \\
<0.05 \\
N S \\
N S \\
\end{array}$ \\
\hline $\begin{array}{c}\mathbf{A S T}, \mathbf{I U} / \mathbf{L}) \\
\text { Mean } \\
\pm \text { SEM } \\
a \\
b \\
c\end{array}$ & $\begin{array}{c}38.3 \\
4.1\end{array}$ & $\begin{array}{c}\mathbf{6 6 . 5} \\
\mathbf{4 . 5} \\
<0.001\end{array}$ & $\begin{array}{c}\mathbf{4 1 . 6} \\
\mathbf{3 . 4} \\
N S \\
<0.001\end{array}$ & $\begin{array}{c}\mathbf{5 1 . 3} \\
\mathbf{2 . 6} \\
<0.05 \\
<0.01 \\
N S\end{array}$ \\
\hline $\begin{array}{c}\mathbf{A L P}, \mathbf{I U} / \mathbf{L}) \\
\text { Mean } \\
\pm \text { SEM } \\
a \\
b \\
c\end{array}$ & $\begin{array}{c}176.6 \\
22.4\end{array}$ & $\begin{array}{c}\mathbf{1 7 5 . 1} \\
\mathbf{3 9 . 4} \\
N S\end{array}$ & $\begin{array}{c}198.9 \\
19.3 \\
N S \\
N S\end{array}$ & $\begin{array}{c}\mathbf{2 0 4 . 2} \\
\mathbf{2 6 . 1} \\
N S \\
N S \\
N S\end{array}$ \\
\hline
\end{tabular}

Data are expressed as mean \pm SEM

No: The number of observations is given in parentheses.

a: Significance of difference from sham control group calculated by LSD at $\mathrm{P} \leq 0.05$.

b: Significance of difference from ischemia reperfusion injury (IR) group calculated by LSD at $\mathrm{P} \leq 0.05$.

c: Significance of difference from topical hypothermia group (TH-IR) calculated by LSD at $\mathrm{P} \leq 0.05$.

NS: Non significant. 
Table (2): Hepatic tissue levels of malondialdehyde (MDA), glutathione peroxidase enzyme (GPX) and tumor necrosis factor alpha (TNF $\alpha$ ) in the different studied groups

\begin{tabular}{|c|c|c|c|c|}
\hline & Sham control & $\begin{array}{c}\text { Ischemia reperfusion } \\
\text { (IR) }\end{array}$ & $\begin{array}{c}\text { Topical hypothermia } \\
\text { (TH-IR) }\end{array}$ & $\begin{array}{c}\text { Ischemic } \\
\text { preconditioning } \\
\text { (IPC-IR) }\end{array}$ \\
\hline $\begin{array}{c}\text { (MDA,nmol/gm) } \\
\text { No. } \\
\text { Mean } \\
\pm \text { SEM } \\
a \\
b \\
c\end{array}$ & $\begin{array}{c}(15) \\
59.8 \\
9.2\end{array}$ & $\begin{array}{c}(11) \\
\mathbf{1 0 0 . 8} \\
\mathbf{8 . 5} \\
\leq 0.001\end{array}$ & $\begin{array}{c}(13) \\
\mathbf{3 1 . 3} \\
\mathbf{6 . 8} \\
<0.01 \\
<0.001\end{array}$ & $\begin{array}{c}(12) \\
\mathbf{7 4 . 6} \\
\mathbf{6 . 3} \\
N S \\
<0.05 \\
<0.001\end{array}$ \\
\hline $\begin{array}{c}\text { (GPX, U/gm) } \\
\text { No. } \\
\text { Mean } \\
\pm S E M \\
a \\
b \\
c \\
\end{array}$ & $\begin{array}{c}(15) \\
151.3 \\
13.6\end{array}$ & $\begin{array}{c}(11) \\
\mathbf{9 9 . 2} \\
\mathbf{2 0 . 5} \\
\leq 0.01\end{array}$ & $\begin{array}{c}(13) \\
162.6 \\
10.7 \\
N S \\
<0.01\end{array}$ & $\begin{array}{c}(12) \\
\mathbf{1 0 5 . 8} \\
\mathbf{1 5 . 8} \\
<0.05 \\
N S \\
\leq 0.01\end{array}$ \\
\hline $\begin{array}{c}\text { (TNF } \boldsymbol{\alpha}, \mathbf{n g} / \mathbf{g m}) \\
\text { No. } \\
\text { Mean } \\
\pm S E M \\
a \\
b \\
c\end{array}$ & $\begin{array}{l}(8) \\
2.68 \\
0.16\end{array}$ & $\begin{array}{c}(8) \\
\mathbf{1 2 . 1 7} \\
\mathbf{0 . 4 2} \\
<0.001\end{array}$ & $\begin{array}{c}(8) \\
\mathbf{9 . 7 6} \\
\mathbf{0 . 4 0} \\
<0.001 \\
<0.001\end{array}$ & $\begin{array}{c}(8) \\
\mathbf{1 0 . 1 9} \\
\mathbf{0 . 4 0} \\
<0.001 \\
\leq 0.001 \\
N S\end{array}$ \\
\hline
\end{tabular}

Data are expressed as mean \pm SEM

No: The number of observations is given in parentheses.

a: Significance of difference from sham control group calculated by LSD at $\mathrm{P} \leq 0.05$.

b: Significance of difference from ischemia reperfusion injury (IR) group calculated by LSD at $P \leq 0.05$.

c: Significance of difference from topical hypothermia group (TH-IR) calculated by LSD at $\mathrm{P} \leq 0.05$.

NS: Non significant.

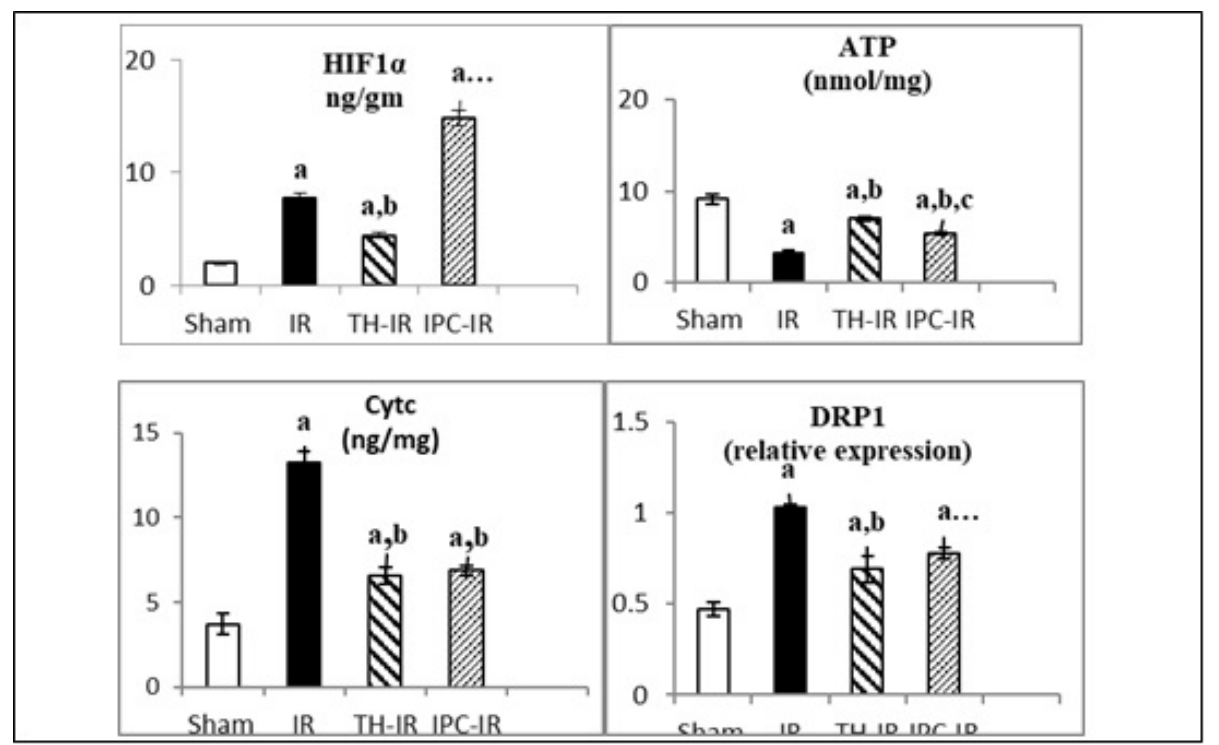

Figure 1: Hepatic tissue levels of hypoxia inducible factor 1 alpha (HIF1 $\alpha$ ), adenosine triphosphate (ATP), cytochrome c (Cyt c) and dynamine related protein 1 (DRP1) in the different studied groups.

Data are expressed as mean \pm SEM

a: Significance of difference from sham control group calculated by LSD at $\mathrm{P} \leq 0.05$.

b: Significance of difference from ischemia reperfusion injury (IR) group calculated by LSD at $\mathrm{P} \leq 0.05$.

c: Significance of difference from topical hypothermia group (TH-IR) calculated by LSD at $\mathrm{P} \leq 0.05$. 


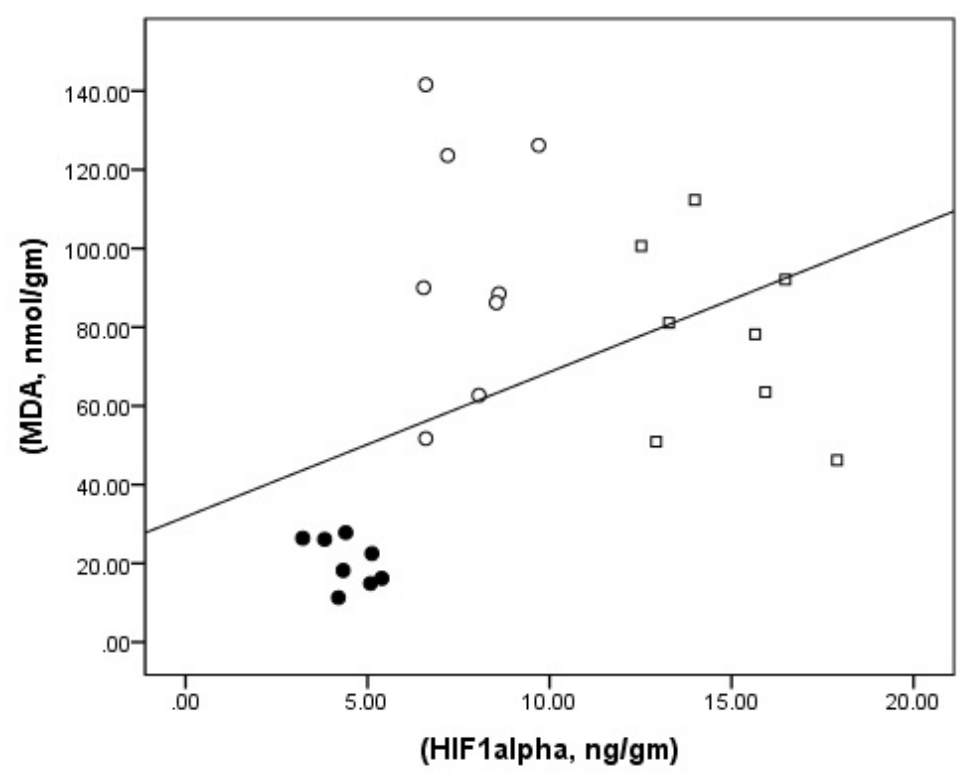

Figure 2: : Correlation between between hypoxia inducible factor 1 alpha (HIF1 $\alpha)$ and malondialdehyde (MDA).

$\mathrm{n}$ : The number of observations.

r: person correlation coefficient.

$\mathrm{P}$ : significance at $\mathrm{P} \leq 0.05$

Table (3): ): Correlation between each of alanine transaminase enzyme (ALT) and aspartate transaminase enzyme (AST) with malondialdehyde (MDA), glutathione peroxidase enzyme (GPX), tumor necrosis factor alpha (TNF $\alpha$ ), cytochrome c (Cyt c), Adenosine triphoshate (ATP) and dynamine related protein 1 (DRP1) in the different studied groups.

\begin{tabular}{|c|c|c|c|c|c|c|c|}
\hline & & $\begin{array}{c}\text { MDA } \\
(\mathbf{n m o l} / \mathrm{gm})\end{array}$ & $\begin{array}{l}\text { GPX } \\
\text { U/gm }\end{array}$ & $\begin{array}{c}\text { TNF } \alpha \\
(\mathrm{ng} / \mathrm{gm})\end{array}$ & $\begin{array}{c}\text { Cyt c c } \\
\text { (ng/mg) }\end{array}$ & $\begin{array}{c}\text { ATP } \\
(\mathbf{n m o l} / \mathbf{m g})\end{array}$ & $\begin{array}{c}\text { DRP1 } \\
\text { (relative } \\
\text { expression) }\end{array}$ \\
\hline \multirow{3}{*}{$\begin{array}{c}\text { ALT } \\
\text { (IU/L) }\end{array}$} & $\mathbf{r}$ & 0.366 & $\begin{array}{c}- \\
0.288\end{array}$ & 0.559 & 0.245 & -0.310 & 0.202 \\
\hline & $\begin{array}{c}P \\
\text { value }\end{array}$ & $<0.05$ & NS & $<0.01$ & NS & NS & NS \\
\hline & No. & 36 & 36 & 25 & 18 & 18 & 18 \\
\hline \multirow{3}{*}{$\begin{array}{c}\mathbf{A S T} \\
(\mathbf{I U} / \mathbf{L})\end{array}$} & $\mathbf{r}$ & 0.446 & $\begin{array}{c}- \\
0.216\end{array}$ & 0.673 & 0.672 & -0.661 & 0.630 \\
\hline & $\begin{array}{c}P \\
\text { value }\end{array}$ & $<0.01$ & NS & $<0.001$ & $<0.01$ & $<0.01$ & $<0.01$ \\
\hline & No. & 36 & 36 & 25 & 18 & 18 & 18 \\
\hline
\end{tabular}

No: The number of observations.

r: person correlation coefficient.

$\mathrm{P}$ : significance at $\mathrm{P} \leq 0.05$

\section{Histological examination with $H \& E$} showed that liver tissue of control group have normal liver architecture formed of cords of hepatocytes hexagonal in shape radiating from central vein with blood sinusoids in-between them (Figure 3). Whereas, liver tissue of IR group stained with H\&E Showed massive distorted liver architecture and destructed hepatocytes in the form 
of degradation of its cytoplasmic content, ballooning of some cells and karyolysis of hepatic cell nuclei (Figure 3). On examination of liver tissue of hypothermia group showed minimal changes of liver tissue with intact hepatocytes and minimal hemorrhage in-between hepatic cells
(Figure 3). On the other hand liver tissue of IPC group, livers showed vacuolation of most of hepatocytes and infiltration of polymorphic inflammatory cells with increased number of eosinophil (Figure 3).

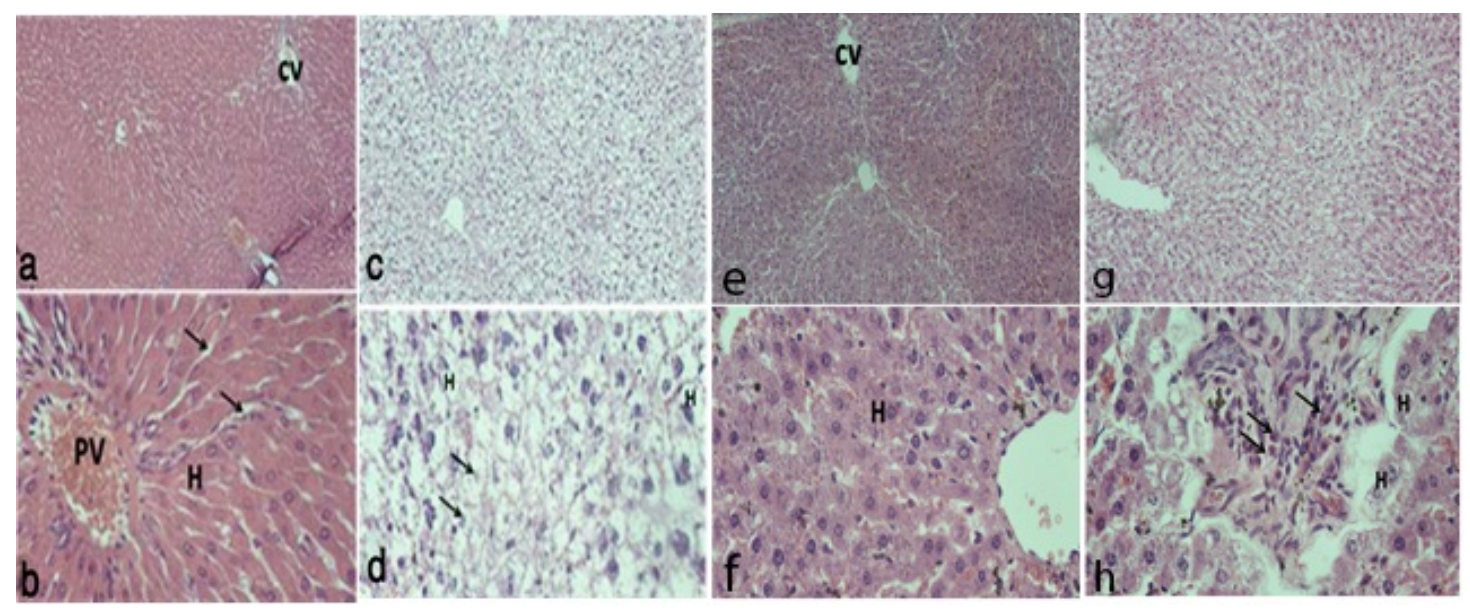

Figure 3: (a\&b): control group: of liver tissue stained with H\&E Showing normal liver architecture formed of cords of hepatocytes $(\mathrm{H})$ hexagonal in shape radiating from central vein (CV) with blood sinusoids ( $\uparrow$ ) in-between them. Notice portal vein $(\mathrm{PV})$. (c \& d): IR group: liver tissue stained with H\&E Showing massive distorted liver architecture and destructed hepatocytes in the form of degradation of its cytoplasmic content, ballooning of some cells $(\mathrm{H})$ and karyolysis of hepatic cell nuclei $(\uparrow)(\mathbf{e} \& \mathbf{f})$ : TH-IR group: of liver tissue of group stained with H\&E Showing minimal changes of liver tissue with intact hepatocytes and minimal hemorrhage in-between hepatic cells. $(\mathrm{CV})$; central vein, $(\mathrm{H})$; hepatocytes, (g\& h): IPC group: liver tissue stained with H\&E Showing vacuolation of most of hepatocytes $(\mathrm{H})$ and infiltration of polymorphic inflammatory cells with increased number of eosinophil (Magnification: a \&C; X100; b \& d ;X400)(Magnification: e\&g; X100; f\&h ;X400).

\section{Discussion:}

Ischemia reperfusion (IR) injury is a clinically important issue in liver transplantation and in flow-controlled surgical operation. This study was aimed to compare between efficacy of ischemic preconditioning (IPC) and topical hypothermia in the protection from oxidant and cellular damage exerted by ischemia reperfusion in liver studying their interaction with cellular and mitochondrial level.

In this study both ALT and AST were significantly increased in IR group compared to sham group this result was in agreement with other studies $(37,38)$. IR injury disturbs the hepatocellular membrane permeability causing hepatic enzymes leakage into the circulation (39). As ALT is more specific to cellular cytoplasm while AST is $20 \%$ specific to cellular cytoplasm and $80 \%$ to mitochondrial matrix (40), it could be concluded that IR injury affect both hepatocytes mitochondria and cytoplasm.

The non-significant changes in the liver enzyme alkaline phosphatase observed in this study among different studied groups could be due to the presence of hepatic ALP on the surface of bile duct epithelia and needs long time of cholestasis to increase $(40,41)$. 
Many studies were consistent to our findings of significantly increased hepatic tissue MDA (38), TNF $\alpha(42,43)$, cytochrome c (an indicator for disruption of mitochondrial integrity) (44), DRP1 (an indicator of increased fission and mitochondrial fragmentation) $(45,46)$ and significant decrease of hepatic ATP levels (an indicator for defective mitochondrial generation of energy) (47) and GPX (48) in cases of IR injury. The previous findings confirm the lesion on cellular and mitochondrial level. The positive significant correlation between the level of AST on one hand with MDA, TNF $\alpha$, Cyt c and DRP1 on the other hand, and its negative correlation with ATP level demonstrated respectively the role of oxidative stress, inflammation, disturbed mitochondrial integrity, dynamics and energetics in pathophysiology of IR injury. It is of interest to see a positive significant correlation between ALT level and both MDA and TNF $\alpha$ without significant correlation with the mitochondrial parameters (ATP, Cyt c and DRP1) supporting that AST is more related to mitochondria involvement.

\section{Common effects to both hypothermia and preconditioning:}

In the current study, both ischemic preconditioning and topical hypothermia exhibited their ability to decrease significantly the level of liver enzyme AST, MDA, TNF $\alpha$, Cyt c and DRP1 compared to IR group.

These changes are supported by other studies with IPC which showed drastic reduction of AST 6 hours after reperfusion (34), significant decrease in TNF $\alpha$ and MDA (49), decreased Cyt c protein expression with both condition of ischemic pre and post conditioning in rats with lightening of apoptosis (50). Although there is a little about changes in DRP1 and in IPC, yet, the increased phagosomes appeared in the histological picture in this study may be supportive to its increase. Recently, in vitro IPC increased mitophagosome formation, enhanced the delivery of mitophagosomes to lysosomes and promoted the clearance of damaged mitochondria in kidney (26). Regarding the conflicting reports about the effects of IPC on hepatic IR injury, although few studies have reported that IPC does not prevent hepatic IR injury (28), we, at least partially, are in agreement with those reported certain beneficial effects and found that IPC can limit the deleterious effects of hepatic IR injury (51).

On the other hand, the previously mentioned effects are supported by other studies with hypothermia which showed significantly reduced AST and ALT using freezing solution dripped on the surface of ischemic lobes (52) reduced IRinduced lipid peroxidation and oxidative stress with mild hypothermia (53). Despite there are no enough knowledge about the relationship between hypothermia, Cyt c and DRP1 in hepatic IR injury, their low levels in this study could be considered indicators for better mitochondrial integrity in hypothermic livers. These results may be supported by an earlier study (54) which found that reducing metabolic demand through hypothermia increased survival and reduced the vulnerability of cortical mitochondria during severe hypoxemia in kidney. Also the inverse correlation between the measured ATP level and Cyt $\mathrm{c}$ in hypothermic group in this study $(r=$ $0.813, p<0.04, n=6)$ (not mentioned in the result) confirmed how the availability of ATP decreased the release of Cyt $\mathrm{c}$ hypothermia has been showed 
to provide neuroprotective against global cerebral IR injury, which is, at least partially, ascribed to the inhibition of DRP1 and Cyt c expression and the protection of mitochondrial structure $(55,56)$. Also hypothermia reported to promote mitochondrial elongation in cardiomyocytes through reduction of DRP1 fission activity together with an associated decrease in cellular $\mathrm{O}_{2}$ consumption (57).

\section{The effects in which hypothermia is more efficient compared to preconditioning:}

Compared to IPC group, hypothermia was more efficient in preservation of integrity of hepatic structure as evidenced by the histological section as well as the significant decrease of both AST and ALT to a level that is not differ significantly from sham control. Whereas IPC showed only ameliorating effect on AST level which even remained significantly higher than control. In this work, the non- significant change in serum ALT in IPC group is consistent to an early study (27). On the other hand, hypothermia was showed to preserve hepatic tissue, prolong cell viability and reduce oxidative stress parameters (58).

Also hypothermia increased the level of hepatic antioxidant GPX concomitant with the reduction of MDA while preconditioning was unable to increase GPX and its effect in reducing MDA was significantly less than that of hypothermia (17). Therefore, topical hypothermia was more effective than IPC in protection of liver against oxidative stress, precluding the need to activate second-line antioxidant defenses to further protects against IPC. In addition, hypothermia was able to increase ATP level significantly more than that of IPC which is an indicator for better mitochondrial function and bioenergetics.

Compared to IR group, hypothermia decreased significantly the level of hypoxia inducible factor (HIF1 $\alpha$ ) while preconditioning increased its level.

Indeed HIF $1 \alpha$ in this study is significantly increased with IR compared to sham control which is consistent with others who reported increased expression of HIF $1 \alpha$ and HIF $2 \alpha$ in many liver diseases including IR-induced liver injury (59). Metabolic reprogramming under hypoxia was one of the first functions ascribed to HIF1 $\alpha$ activity. HIF $1 \alpha$ is continuously synthesized in the cytosol and is rapidly degraded by the $26 \mathrm{~S}$ proteasome under normoxic conditions in contrast to proteolytically stable beta subunit. When oxygen is limiting, HIF $\alpha$ became stabilized and then translocated to the nucleus where it binds to specific gene named hypoxia response elements (HREs). Thereafter, accumulated HIF $\alpha$ dimerise with HIF $\beta$ subunits and recruit additional transcriptional co-activators to transactivate the transcription of hypoxia-responsive genes (60).

HIF $1 \alpha$ signaling is considered to support anaerobic ATP production by upregulating glycolytic enzymes $(61,62)$ and downregulating oxidative phosphorylation enzymes thus reducing the cell's reliance on oxygen-dependent energy production (63). Also HIF1 signaling is important for HIF-mediated suppression of ROS. HIF signaling also up-regulates the expression of SOD, a mitochondrial enzyme capable of converting the superoxide free radical to $\mathrm{H}_{2} \mathrm{O}_{2}$ which can then be converted to harmless water and oxygen by catalase enzymes. HIF mediates also regulation of mitochondrial mass and mediate 
adaptive responses to tissue hypoxia (60).

The enhanced expression of HIF1 $\alpha$ with ischemic preconditioning in this study is described before in hepatocytes (64) where HIF $1 \alpha$ activation was reported to be associated with the induction of a long lasting tolerance to hypoxic injury (65) and to promote cell survival during IR liver injury $(66,67)$. However, despite its increased expression with IPC as manifested in this study, it did not provide valuable protection against IR injury.

Also the reduced expression of HIF1 $\alpha$ with hypothermia may be attributed to ability of hypothermia to improve REDOX state compared to IR and IPC (decreased MDA and increased GPX) since stabilization HIF $\alpha$ in the start of hypoxia is attributed to ROS (68). Herein, the positive significant correlation between MDA and level if HIF is supportive to this concept. Also the ability of hypothermia to reduce the inflammatory insult on hepatocyte manifested by the reduced $\mathrm{TNF} \alpha$ level may explain its role in inhibiting HIF1 $\alpha$ expression since inflammation and its mediators are HIF activators (69).

In addition, the effect of hypothermia in reducing Cyt c may be an additive role. It has been showed before that nitric oxide produced by cytochrome c oxidase helps in stabilization of HIF1 $\alpha$ in hypoxic mammalian cells (70).

\section{Conclusion:}

Hypothermia showed more efficacy compared to IPC in protection against hepatic IR injury. The effect of hypothermia in reducing this metabolic reprogramming signal (HIF $1 \alpha$ ) did not prevent its overwhelming effect in protection against IR injury compared to IPC. So, the protection, therefore, appears to be HIF1 $\alpha$ independent and may be accomplished through other interactive mechanisms. Hypothermia induced its effect through improvement of REDOX state and mitochondrial bioenergetics.

\section{References}

1. Ren $\mathbf{J}$ and Zhang $\mathbf{Y}$ : Editorial: new therapetic approaches in the management of ischemia reperfusion injury and cardiometabolic diseases: opportunities and challenges, Curr. Drug Targets; 18(15):1687-1688, 2017.

2. Fann DY, Lee SY, Manzanero S, Chunduri P, Sobey CG and Arumugam TV: "Pathogenesis of acute stroke and the role of inflammasomes," Ageing Res Rev; 12(4): 941- 66, 2013.

3. Salvadori M, Rosso $G$ and Bertoni E: Update on ischemia-reperfusion injury in kidney transplantation: pathogenesis and treatment. World $J$ Transplant; 5: 52-67, 2015.

4. Papadopoulos D, Siempis T, Theodorakou E and Tsoulfas G: Hepatic ischemia and reperfusion injury and trauma: current concepts. Archives of Trauma Research; 2(2):63-70, 2013.

5. Konishi $\mathbf{T}$ and Lentsch AB: Hepatic Ischemia/Reperfusion:Mechanism of Tissue Injury, Repair, and Regeneration. Gene Expr; (17)(4): 277-287, 2017.

6. Wu MY, Yiang GT, Liao WT, Tsai AP, Cheng YL, Cheng PW, LiCY and LiCJ: Current Mechanistic Concepts in Ischemia and Reperfusion Injury.Cell PhysiolBiochem; 46(4):1650-1667, 2018.

7. Nakazato PCG, Victorino JP, Fina CF, Mendes KDS, Gomes MCJ, Evora PRB, D'Albuquerque LAC and Castro-E-Silva 
O: Liver ischemia and reperfusion injury. Pathophysiology and new horizons in preconditioning and therapy. Acta Cir Bras; 33(8):723-735, 2018.

8. Cannistrà M, Ruggiero $\mathbf{M}$, Zullo A, Gallelli, G, Serafini S, Maria M, Naso A, Grande R, Serra R and Nardo B: Hepatic ischemia reperfusion injury: a systematic review of literature and the role of current drugs and biomarkers. Int J Surg.; 33:S57S70, 2016.

9. Van Golen RF, Reiniers MJ, Vrisekoop N, Zuurbier CJ, Olthof PB, van Rheenen J, van Gulik TM, Parsons BJ and Heger M: The mechanisms and physiological relevance of glycocalyx degradation in hepatic ischemia/reperfusion injury. Antioxid REDOX Signal; 21(7):1098-118, 2014.

10. Ling Q, Yu X, Wang T, Wang SG, Ye ZQ and Liu JH: Roles of the Exogenous H2SMediated SR-A Signaling Pathway in Renal Ischemia/ Reperfusion Injury in Regulating Endoplasmic Reticulum Stress-Induced Autophagy in a Rat Model. Cell PhysiolBiochem; 41: 2461-2474, 2017.

11. Zhou H. Wang J, Hu S, Zhu H, Toanc S, Ren J: BI1 alleviates cardiac microvascular ischemia reperfusion injury via modifying mitochondrial fission and inhibiting XO/ROS/F-actin pathways. J. Cell Physiol234: 5056-5069, 2019.

12. Miyazawa T, Tamura A, Fukui $\mathbf{S}$ and Hossmann KA: Effect of mild hypothermia on focal cerebral ischemia. Review of experimental studies. Neurol Res.; 25:457464, 2003.
13. Delbridge MS, Shrestha BM, Raftery AT, El Nahas AM and Haylor JL: The effect of body temperature in a rat model of renal ischemia-reperfusion injury. Transplant Proc; 39: 2983-2985, 2007.

14. SeltenJ, SchlegelA, de Jonge $J$ and Dutkowski P: Hypo-And Normothermic Perfusion of the Liver: Which Way to Go? Best Pract Res Clin Gastroenterol; 31(2):171-179, 2017.

15. Dash R, Mitsutake Y, Pyun WB, Dawoud F, Lyons J, Tachibana A, Yahagi K, Matsuura Y, Kolodgie FD, Virmani R, McConnell MV, Illindala U, Ikeno F and Yeung A:Dose-Dependent Cardioprotection of Moderate $\left(32^{\circ} \mathrm{C}\right)$ Versus Mild $\left(35^{\circ} \mathrm{C}\right)$ Therapeutic Hypothermia in Porcine Acute Myocardial Infarction. JACC CardiovascInterv.22; 11(2):195-205, 2018.

16. Kron P,Schlegel A, Mancina L, Clavien PA and Dutkowski P: Hypothermic oxygenated perfusion (HOPE) for fatty liver grafts in rats and humans.J Hepatol.; 68:8291, 2017.

17. Longo L, Sinigaglia-Fratta LX, Weber GR, Janz-Moreira A, Kretzmann NA, Grezzana-FilhoTde J, Possa-Marroni N, Corso CO, Schmidt-Cerski CT, Reverbelda-Silveira T, Álvares-da-Silva MR and dos-Santos JL: Hypothermia is better than ischemic precon ditioning for preventing early hepatic ischemia/reperfusion in rats. Ann Hepatol; 15(1):110-20, 2016.

18. Xiao Q, Ye Q, Wang W, Xiao J, Fu B, Xia Z, Zhang $X$, Liu $Z$ and Zeng $X$ : Mild hypothermia pretreatment protects against 
liver ischemia reperfusion injury via the PI3K/AKT/FOXO3a pathway.Mol Med Rep.; 16(5): 7520-7526, 2017.

19. Martins RM, Teodoro JS, Furtado E, Oliveira RC, Tralhão JG, Rolo AP and Palmeira CM: Mild hypothermia during the reperfusion phase protects mitochondrial bioenergetics against ischemia-reperfusion injury in an animal model of ex-vivo liver transplantation-an experimental study.Int $\mathbf{J}$ Med Sci.; 16(9):1304-1312, 2019.

20. Carbonell T, Alva N, Sanchez-Nuño S, Dewey S, and Gomes AV:Subnormothermic Perfusion in the Isolated Rat Liver Preserves the Antioxidant Glutathione and Enhances the Function of the Ubiquitin Proteasome System. Oxid Med Cell Longev; 2016:9324692, 2016.

21. Khalilov RA, Dzhafarova AM and Khizrieva SI: Effect of Hypothermia on Kinetic Characteristics of Lactate Dehydrogenase in Rat Brain under Conditions of Global Ischemia and Reperfusion. Bull. Exp. Biol. Med;163: 313317, 2017.

22. Alva N, Bardallo RG, Basanta D, Palomeque $J$ and Carbonell $T$ : Preconditioning-Like Properties of ShortTerm Hypothermia in Isolated Perfused Rat Liver (IPRL) SystemInt J Mol Sci.; 19(4): 1023, 2018.

23. De Rosa S, Antonelli $M$ and Ronco $C$ : Hypothermia and kidney: a focus on ischaemia-reperfusion injury. Nephrol Dial Transplant. 1; 32(2):241-247, 2017.

24. Souza PC, Santos EBD, Motta GL, Bona SR, Schaefer PG, Campagnol D, Bortolini
T and Corso CO: Combined effects of melatonin and topical hypothermia on renal ischemia-reperfusion injury in rats.Acta Cir Bras.; 33(3):197-206, 2018.

25. Rana A, Goyal N, Ahlawat A, Jamwal S, Reddy BV and Sharma S: Mechanisms involved in attenuated cardio-protective role of ischemic preconditioning in metabolic disorders. Perfusion; 30: 94-105, 2015.

26. Livingston MJ, Wang J, Zhou J, Wu G, Ganley IG, Hill JA, Yin XM and Dong Z: Clearance of damaged mitochondria via mitophagy is important to the protective effect of ischemic preconditioning in kidneys.Autophagy; $\quad$ 15(12):2142-2162, 2019.

27. Zhang Y, Shen Q, Liu Y, Chen H, Zheng $\mathbf{X}$, Xie S, Ji $\mathbf{H}$ and Zheng S: Hepatic Ischemic Preconditioning Alleviates Ischemia-Reperfusion Injury by Decreasing TIM4 Expression. Int $J$ Biol Sci; 14(10):1186-1195, 2018.

28. Zapata-Chavira HA, Cordero-Pérez P, Casillas-Ramírez A, Escobedo-Villarreal MM, Pérez-Rodríguez E, TorresGonzález L，Camara-Lemarroy C, Hernández-Guedea MA, CaballeroMendoza E and Muñoz-Espinosa LE: Is Ischemic Preconditioning a Useful Therapeutic Strategy in Liver Transplantation? Results from the First Pilot Study in Mexico. Arch Med Res; 46:296302, 2015.

29. Barnes CD and Etherington LG: Drug dosage in laboratory animals, a hand book. University of California Press and Los Anglos P: 41, 1964. 
30. Lin HC, Liu SY, Lai HS and Lai IR: Isolated mitochondria infusion mitigates ischemia-reperfusion injury of the liver in rats: reply. Shock; 39(6):543, 2013.

31. Glanemann M, Vollmar B, Nussler AK, Schaefer T, Neuhaus $P$ and Menger MD: Ischemic preconditioning protects from hepatic ischemia/reperfusion-injury by preservation of microcirculation and mitochondrial REDOX-state.J Hepatol; 38(1): 59-66, 2003.

32. Liu B, Ma ZY, Wu $G$ and Qian JM: Butyrate protects rats from hepatic ischemia/reperfusion injury. Int $J$ Clin Exp Med.; 8(4):5406-13. 2015.

33. Abdo EE, Figueira ERR, Rocha-Filho JA, Chaib E, D'Albuquerque LAC and Bacchella T: Preliminary results of topical hepatic hypothermia in a model of liver ischemia/reperfusion injury in rats.arqgastroenterol; 54(3):246-249, 2017.

34. Liu A, Fang H, Wei W, Dirsch $O$ and Dahmen U: Ischemic preconditioning protects against liver ischemia/reperfusion injury via heme oxygenase-1-mediated autophagy.Crit Care Med; 42(12):e762-71, 2014.

35. Bancroft $\mathbf{J} \mathbf{D}$ and Gamble M: Theory and practice of histological techniques, sixth edition, Churchill Livingstone Elsevier, pp: 126, 150, 171, 60, 2008.

36. Armitage $\mathbf{P}$ and Berry G: Statistical methods in medical research, $2^{\text {nd }}$ edition. Blackwell Scientific Puplications, 1987.

\section{ParikhMP,PatelAM,PatelKVandGandhi}

TR: "Protective effect of Momordicacharantia against hepatic ischemic reperfusion injury model in rats," Austin Journal of Pharmacology and Therapeutics. 3(1): 1064, 2015.

38. Sherif IO and Al-Shaalan NH: Vildagliptin Attenuates Hepatic Ischemia/ Reperfusion Injury via the TLR4/NF- $\kappa$ B Signaling Pathway. Oxid Med Cell Longev; 2018:3509091, 2018.

39. Jiao SF, Sun K, Chen XJ, Zhao X, Cai N, Liu YJ, Xu LM, Kong XMand Wei LX: "Inhibition of tumor necrosis factor alpha reduces the outgrowth of hepatic micrometastasis of colorectal tumors in a mouse model of liver ischemia-reperfusion injury," J Biomed Sci; 21(1):1, 2014.

40. Giannini EG, Testa R, and Savarino V: Liver enzyme alteration: a guide for clinicians.CMAJ; 172(3): 367-79, 2005.

41. Moss DW: Physicochemical and Pathophysiological Factors in the Release of Membrane-Bound Alkaline Phosphatase From Cells ClinChimActa; 257(1):133-40, 1997.

42. Atalay S, Soylu B, Aykaç A, Öğünç AV, Çetinel Ş, Özkan N, Erzik Cand Şehirli AÖ: Protective effects of St. John's wort in the hepatic ischemia/reperfusion injury in rats. Turk J Surg; 34(3):198-204, 2018.

43. Mustafa HN, Hegazy GA, El Awdan SA and Alamoudi AA: Liver ischemia/reperfusion injury, a setting in which the functional mass is reduced and the role of PDE5 inhibitor. Eur J Anat, 23 (5): 325-332, 2019.

44. Eleftheriadis T, Pissas G, Liakopoulos V and Stefanidis I: Cytochrome $\mathrm{c}$ asa Potentially Clinical Usefu 
1 Marker of Mitochondrial and Cellular Dam age. Front Immunol.; 7:279, 2016.

45. Lee WH, Higuchi H, Ikeda S, Macke EL, Takimoto T, Pattnaik BR, Liu C, Chu LF, Siepka $\quad$ SM, Krentz KJ, Rubinstein CD, Kalejta RF, Thomson JA, Mullins RF, Takahashi JS, Pinto LH and Ikeda A: "Mouse Tmem135 mutation reveals a mechanism involving mitochondrial dynamics that leads to agedependent retinal pathologies," Elife; 5:e19264, 2016.

46. Vantaggiato C, Castelli M, Giovarelli M, Orso G, Bassi MT, Clementi E and De Palma C: The Fine Tuning of Drp1Dependent Mitochondrial Remodeling and Autophagy Controls Neuronal Differentiation.Front Cell Neurosci. ; 13:120. Immunol.; 7:279, 2019.

47. Go KL, Lee S, Zendejas I, Behrns KE and Kim JS: Mitochondrial Dysfunction and Autophagy i n Hepatic Ischemia/Reperfusion Injury. Biomed Res Int.; 2015:183469, 2015.

48. Akbari G, Mard SA, Dianat $M$ and Mansouri E: The Hepatoprotective and MicroRNAs Downregulatory Effects of Crocin Following Hepatic IschemiaReperfusion Injury in Rats. Oxid Med Cell Longev; 2017: 1702967, 2017.

49. Adam A: Some mechanisms of the protective effect of ischemic preconditioning on rat liver ischemiareperfusion injury. Int J Gen Med. Int J Gen Med; 7: 483-9, 2014.

50. Chu WW, HeXY, Yan AL, Wang SW, LiS, Nian S, Wang YL and LiangFL:
Ischemic Postconditioning Lightening Ischemia/Reperfusion Apoptosis of Rats via Mitochondria Pathway. Eur Rev Med PharmacolSci; 23(14):6307-6314, 2019.

51. Chu MJ, Vather R, Hickey AJ, Phillips AR and Bartlett AS: Impact of ischaemic preconditioning on experimental steatotic livers following hepatic ischaemiareperfusion injury: a systematic review. HPB (Oxford); 17:1-10, 2015.

52. Gabiatti G, Grezzana-Filho TJM, Cerski CTS, Bofill $C$, Valle $S$ and Corso CO:Topical hepatic hypothermia associated with ischemic preconditioning. Histopathological and biochemical analysis of ischemia reperfusion damage in a 24 hour model 1.Acta Cir Bras; 33(10):924-934, 2018.

53. Wang J, Toan $\mathbf{S}$ and Zhou H: Mitochondroial quality control in cardiac microvascular ischemia reperfusion injury: New insights into the mechanisms and therapeutic potentials. Pharmacol Res; 156:104771, 2020.

54. Chisholm KI, Ida KK, Davies AL, Tachtsidis I, Papkovsky DB, Dyson A, Singer M, Duchen MR and Smith KJ: Hypothermia protects brain mitochondrial function from hypoxemia in a murine model of sepsis. Version 2. J Cereb Blood Flow Metab.; 36(11):1955-1964, 2016.

55. Tang Y, Liu X, Zhao J, Tan X, Liu B, Zhang G, Sun L, Han D, Chen $H$ and Wang M:Hypothermia-induced ischemic tolerance is associated with Drp1 inhibition in cerebral ischemia-reperfusion injury of mice.Brain Res; 1646:73-83, 2016. 
56. Fan J, Cai S, Zhong H, Cao L, Hui K, Xu M, Duan $M$ and $\mathrm{Xu}$ J:Therapeutic hypothermia attenuates global cerebral reperfusion-induced mitochondrial damage by suppressing dynamin-related protein 1 activation and mitochondria-mediated apoptosis in a cardiac arrest rat model.NeurosciLett.; 647:45-52, 2017.

57. Sharp WW, Fang YH, Han M, Zhang HJ, Hong Z, Banathy A, Morrow E, Ryan JJ and Archer SL:Dynamin related protein 1 (Drp1)-

mediated diastolic dysfunction in myocardia 1 ischemia

reperfusion injury: therapeutic benefits of $\mathrm{D}$ rp1 inhibition to reduce mitochondrial fissio n.FASEB J; 28(1):316-26, 2014.

58. Ferrigno A, Carlucci F, Tabucchi A, Tommassini V, Rizzo V, Richelmi P, Gringeri E, Neri D, Boncompagni E, Freitas I, Cillo $U$ and Vairetti $M$ : Different susceptibility of liver grafts from lean and obese Zucker rats to preservation injury.Cryobiology; 59(3):327-34, 2009.

59. Novo E, Povero D, Busletta C, Paternostro C, di Bonzo LV, Cannito S, Compagnone A, Bandino A, Marra F, Colombatto S, David E, Pinzani $M$ and Parola M: The biphasic nature of hypoxiainduced directional migration of activated human hepatic stellate cells.J Pathol.; 226(4):588-97, 2012.

60. Thomas LW and Ashcroft M:Exploring the molecular interface between hypoxiainducible factor signalling and mitochondria.Cell Mol Life Sci; 76(9):17591777, 2019.
61. Semenza GL, Roth PH, Fang HM and Wang GL: Transcriptional regulation of genes encoding glycolytic enzymes by hypoxia-inducible factor 1. J BiolChem; 269(38):23757-63, 1994.

62. Semenza GL, Jiang BH, Leung SW, Passantino R, Concordet JP, Maire P and Giallongo A: Hypoxia response elements in the aldolase A, enolase 1, and lactate dehydrogenase A gene promoters contain essential binding sites for hypoxia-inducible factor 1. J BiolChem; 271(51):32529-37, 1996.

63. Papandreou I, Cairns RA, Fontana L, Lim AL and Denko NC: HIF-1 mediates adaptation to hypoxia by actively downregulating mitochondrial oxygen consumption. Cell Metab. 3 (3):187-97, 2006.

64. Cursio R, Miele C, Filippa N, Van Obberghen E and Gugenheim $\mathbf{J}$ : Liver HIF-1alpha induction preceds apoptosis following normothermic ischemiareperfusion in rats. Transplant Proc; 40(6): 2042-5, 2008.

65. Alchera E, Tacchini L, Imarisio C, Dal Ponte C, De Ponti C, Gammella E, Cairo G, Albano E and Carini R: Adenosinedependent activation of hypoxia-inducible factor-1 induces late preconditioning in liver cells. Hepatology; 48:230-239, 2008.

66. Guo JY, YangT, Sun XG, Zhou NY, Li FS, Long D, LinT, Li PY and Feng L: Ischemic postconditioning attenuates liver warm ischemia-reperfusion injury through Akt-eNOS-NO-HIF pathway. J Biomed Sci; 18(1):79, 2011. 
67. Song $X$, Zhang $\mathbf{N}, \mathbf{X u} \mathrm{H}$, Cao $L$ and Zhang H:Combined preconditioning and postconditioning provides synergistic protection against liver ischemic reperfusion injury.Int J Biol Sci.; 8(5):707-18, 2012.

68. Guzy RD, Hoyos B, Robin E, Chen H, Liu L, Mansfield KD, Simon MC, Hammerling $U$ and Schumacker PT: Mitochondrial complex III is required for hypoxia-induced ROS production and cellular oxygen sensing. Cell Metab; 1(6):401-8, 2005.

69. Tannahill GM, Curtis AM, Adamik J, Palsson-McDermott EM, McGettrick AF, Goel G, Frezza C, Bernard NJ, Kelly B,
Foley NH, Zheng L, Gardet A, Tong Z, Jany SS, Corr SC, Haneklaus M, Caffrey BE, Pierce K, Walmsley S, Beasley FC, Cummins E, Nizet V, Whyte $M$, Taylor CT, Lin H, Masters SL, Gottlieb E, Kelly VP, Clish C, Auron PE, Xavier RJ and O'Neill LA.: Succinate is an inflammatory signal that induces IL-1beta through HIF1alpha. Nature; 496(7444):238-42, 2013.

70. Ball KA, Nelson AW, Foster DG and Poyton RO: Nitric oxide produced by Cytochrome c oxidase helps stabilize HIF$1 \alpha$ in hypoxic mammalian cells. BiochemBiophys Res Commun.; 420(4):72732, 2012. 